\title{
Liriopesides B induces apoptosis and cell cycle arrest in human non-small cell lung cancer cells
}

\author{
HONGXU SHENG, WANG LV, LINHAI ZHU, LUMING WANG, ZHITIAN WANG, JIA HAN and JIAN HU \\ Department of Thoracic Surgery, The First Affiliated Hospital, School of Medicine, \\ Zhejiang University, Hangzhou, Zhejiang 350002, P.R. China
}

Received January 23, 2020; Accepted May 22, 2020

DOI: $10.3892 /$ ijmm.2020.4645

\begin{abstract}
Although significant progress has been made in the treatment of lung cancer, it remains the leading cause of cancer-associated mortality. Liriopesides B (LPB) is a natural product isolated from the tuber of Liriope platyphylla, whose effective substances have exhibited antitumor activity in several types of cancer. However, the functions of LPB in non-small cell lung cancer (NSCLC) require further investigation. Therefore, the present study aimed to investigate whether LPB influences the pathogenic effects of NSCLC. In the present study, it was demonstrated that LPB reduced proliferation, and induced apoptosis and cell cycle arrest in non-small cell lung cancer cells. CCK- 8 and colony formation assays demonstrated that LPB decreased cell viability and proliferation of H460 and H1975 cells in a dose-dependent manner. Flow cytometry revealed that LPB significantly induced apoptosis of NSCLC cells, along with changes in the expression of apoptosis-associated proteins, including an increase in Bax, caspase-3, and caspase- 8 expression, and a decrease in Bcl-2 and Bcl-xl expression. LPB inhibited the progression of the cell cycle from the $\mathrm{G} 1$ to the $\mathrm{S}$ phase. Furthermore, autophagy was increased in cells treated with LPB. Finally, the expression of programmed death-ligand 1 was significantly decreased by LPB. In conclusion, the results of the present study highlight a potential novel strategy for the clinical treatment of NSCLC.
\end{abstract}

\section{Introduction}

Lung cancer is the most commonly diagnosed type of cancer, accounting for $11.6 \%$ of all cases, and is the leading cause of cancer-associated mortality, accounting for $18.4 \%$ of all cancer-associated deaths worldwide in 2018 (1). Lung cancer

Correspondence to: Professor Jian Hu, Department of Thoracic Surgery, The First Affiliated Hospital, School of Medicine, Zhejiang University, 79 Qingchun Road, Hangzhou, Zhejiang 350002, P.R. China

E-mail: dr_hujian@zju.edu.cn

Key words: liriopesides B, apoptosis, cell cycle, autophagy, programmed death-ligand 1 , non-small cell lung cancer is classified into two main categories, non-small cell lung cancer (NSCLC) and small cell lung cancer, of which the former accounts for $\sim 85 \%$ of all cases (2). NSCLC is further subdivided into three major pathological types, squamous cell carcinoma, adenocarcinoma and large cell carcinoma (3). With the increase in the use of low-dose computed-tomography screening and the overall improvement in public health awareness, the detection of early lung cancer is increasing annually, along with a decrease in mortality rates (4); however, lung cancer is often initially diagnosed as advanced or locally advanced, particularly in less economically developed regions (5). Therefore, although significant progress has been made in the diagnosis and clinical treatment of lung cancer, the 5-year overall survival rate remains at $\sim 19 \%$ in 2019 (6). Identifying novel candidate molecules involved in lung cancer or effective drugs for clinical treatment to improve the overall survival of lung cancer is therefore urgently required.

Traditional Chinese herbal medicine has gained increasing attention as novel anticancer drugs or novel clinical adjuvants to improve chemotherapy, or to relieve the related side effects (7). Liriope platyphylla (LP), a medical plant predominantly found in China, Korea and Japan, has been used to treat persistent coughs, neurodegenerative diseases and asthma (8), due to its anti-bacterial and anti-inflammatory effects $(9,10)$, as well as its ability to improve memory (11). In addition, steroidal saponins, the primary bioactive constituents of various medical plants, including LP, exhibit anticancer effects against several types of cancer cells, including breast, colorectal, and prostate cancer cells (12-15). Furthermore, it has been reported that the abundance of steroidal saponins in LP contributes to the biological properties of LP $(16,17)$. Liriopesides B (LPB), a traditional herb isolated from the roots of LP, exhibits antitumor activity in human ovarian cancer cells (18). However, to the best of our knowledge, the potential therapeutic effects of LPB in NSCLC remain unknown. Due to their lower toxicity and better tolerability compared with unnatural products, natural products may be ideal candidates for cancer treatment, and this may explain the widespread interest among researchers worldwide (7).

In the present study, the antitumor effects of LPB on H460 and H1975 cells were assessed. LPB inhibited proliferation, induced apoptosis, increased autophagy and caused G1/S phase arrest. Furthermore, LPB also downregulated the expression of PD-L1 both at the transcriptional and translational levels. 
These results highlight the potent antitumor effects of LPB, suggesting that LPB may serve as a novel strategy for the clinical treatment of NSCLC.

\section{Materials and methods}

Cell lines and cell culture. H460 and H1975 cells, which have relatively high expression of PD-L1, were selected to be used in the present study. Both cell lines were purchased from The Cell Bank of Type Culture Collection of the Chinese Academy of Sciences. Both cell lines were cultured in RPMI-1640 medium (Corning, Inc.) with 10\% FBS (Corning, Inc.), penicillin $(100 \mathrm{IU} / \mathrm{ml})$ and streptomycin $(100 \mu \mathrm{g} / \mathrm{ml})$ in an incubator with $5 \% \mathrm{CO}_{2}$ at $37^{\circ} \mathrm{C}$.

Antibodies and reagents. The following antibodies were purchased from Cell Signaling Technology, Inc.: Anti-poly (ADP-ribose) polymerase (PARP; cat. no. 9532; 1:1,000), anti-cleaved PARP (cat. no. 5625; 1:1,000), anti-caspase-3 (cat. no. 9662; 1:1,000), anti-cleaved caspase-3 (cat. no. 9664; 1:1,000), anti-caspase-9 (cat. no. 9502; 1:1,000), anti-cleaved caspase-9 (cat. no. 9501; 1:1,000), anti-cleaved caspase-8 (cat. no. 9496; 1:1,000), anti-Survivin (cat. no. 2808; 1:1,000), anti-Bax (cat. no. 5023; 1:1,000), anti-Bcl-2 (cat. no. 4223; 1:1,000), anti-Bid (cat. no. 2002; 1:1,000), anti-Bcl-xl (cat. no. 2764; 1:1,000), anti-cytochrome c (cat. no. 4280; 1:1,000), anti-cox IV (cat. no. 4850; 1:1,000), anti-programmed death-ligand 1 (PD-L1; cat. no. 78701; 1:1,000), anti-phosphorylated (p)-ERK1/2 (Thr202/Tyr204; cat. no. 4370; 1:1,000), anti-ERK1/2 (cat. no. 4695; 1:1,000), anti-p-JNK (Thr183/Tyr185; cat. no. 9251; 1:1,000), anti-JNK (cat. no. 9252; 1:1,000), anti-p-P38 (Thr180/Tyr182; cat. no. 9211; 1:1,000), anti-P38 (cat. no. 9212; 1:1,000), anti-p-AKT (Ser473, cat. no. 4060; 1:1,000), anti-AKT (cat. no. 9272; 1:1,000), anti- $\beta$-actin (cat. no. 3700; 1:2,000), anti-p-retinoblastoma (Rb; Ser807/811; cat. no. 8516; 1:1,000), anti-Rb (cat. no. 9313; 1:1,000), anti-P21 (cat. no. 2947; 1:1,000), anti-CDK6 (cat. no. 3136; 1:1,000), anti-cyclin D1 (cat. no. 2978; 1:1,000), anti-cyclin D3 (cat. no. 2936; 1:1,000), anti-GAPDH (cat. no. 97166; 1:2,000), anti-AMP-activated protein kinase $\alpha$ (AMPK $\alpha$; cat. no. 5831; 1:1,000), anti-Unc-51 like autophagy activating kinase (ULK1; cat. no. 8054; 1:1,000), anti-p-ULK1 (Ser555; cat. no. 5869; 1:1,000), anti-p-AMPKa (Thr172; cat. no. 50081; 1:1,000), anti-mTOR (cat. no. 2983; 1:1,000) and anti-p-mTOR (Ser2448; cat. no. 5536; 1:1,000). Anti-tBid (cat. no. ab10640; Abcam; 1:1,000), anti-CD274 (cat. no. 557924; BD Pharmingen; BD Biosciences), anti-IgG (cat. no. 556650; BD Pharmingen; BD Biosciences) and $\mathrm{Fc}$ block (cat. no. 564765; BD Pharmingen; BD Biosciences) were also purchased.

Cell Counting Kit-8 (CCK-8) assay. Cell viability was determined using a CCK- 8 assay (Beyotime Institute of Biotechnology) assay. Cells were seeded in 96-well plates $\left(5 \times 10^{3}\right.$ per well) and incubated with LPB (purity $\geq 98 \%$; Chengdu Must Bio-Technology Co., Ltd.) at $37^{\circ} \mathrm{C}$ for 24 or $48 \mathrm{~h}$ at different concentrations $(0,10,20,30,40,50$ and $60 \mu \mathrm{M}$ ). Subsequently, $10 \mu \mathrm{l}$ CCK-8 solution was added to the cells, and further incubated at $37^{\circ} \mathrm{C}$ for $1 \mathrm{~h}$. The absorbance was measured at $450 \mathrm{~nm}$ using a microplate spectrophotometer. A total of five wells were used for each experimental condition.

Colony formation assay. $\mathrm{H} 460$ and $\mathrm{H} 1975$ cells were seeded into 6-well plates at a density of $1 \times 10^{3}$ cells per well. Following treatment with $\operatorname{LPB}(0,20,40$ and $60 \mu \mathrm{M})$ for $\sim 2$ weeks at $37^{\circ} \mathrm{C}$, cells were washed with PBS twice, then fixed in $4 \%$ paraformaldehyde for $30 \mathrm{~min}$ at $4^{\circ} \mathrm{C}$, and stained with $0.5 \%$ crystal violet for $20 \mathrm{~min}$ at room temperature. Visualized colonies were then imaged and counted.

Annexin V-FITC/PI double staining. Apoptosis was quantified using a FITC Annexin V Apoptosis Detection kit I (cat. no. 556547; BD Pharmingen; BD Biosciences) according to the manufacturer's protocol. Cells were treated with the indicated concentrations $(0,20,40$ and $60 \mu \mathrm{M})$ of LPB for $24 \mathrm{~h}$ at $37^{\circ} \mathrm{C}$. Subsequently, cells were collected and washed twice with PBS. Subsequently, $1 \times 10^{6}$ cells were resuspended in $100 \mu \mathrm{l} 1 \mathrm{X}$ binding buffer (diluted with $\mathrm{ddH}_{2} \mathrm{O}$ ), and $5 \mu \mathrm{l}$ FITC and $5 \mu 1$ PI were added to each tube and incubated for $30 \mathrm{~min}$ at room temperature in the dark. After staining, $500 \mu \mathrm{l}$ $1 \mathrm{X}$ binding buffer was added to each tube before analysis using a flow cytometer and FlowJo v10.4 software (FlowJo LLC).

Hoechst 33342 staining. Characteristic apoptotic morphological changes were assessed by fluorescence microscopy using Hoechst 33342 (cat. no. 145331; Sigma-Aldrich; Merck KGaA). Briefly, the cells were seeded in 6-well plates at a density of $1 \times 10^{6}$ per well, followed by treatment with LPB $(0,20,40$ and $60 \mu \mathrm{M})$ for $24 \mathrm{~h}$ at $37^{\circ} \mathrm{C}$. Cells were washed with PBS twice and then stained with $5 \mu \mathrm{g} / \mathrm{ml}$ Hoechst 33342 for $15 \mathrm{~min}$ at room temperature in the dark. Following staining, cells were observed with a fluorescence microscope (magnification, x200).

Western blot analysis. Cell lysates were prepared using RIPA lysis buffer containing protease inhibitor (cat. no. 5892970001; Roche Diagnostics) and phosphatase inhibitor (cat. no. 524629; EMD Millipore). Following quantitation using a BCA Protein assay kit (Pierce; Thermo Fisher Scientific, Inc.), equal quantities of proteins (20-30 $\mu \mathrm{g} / \mathrm{lane})$ were loaded on a $12 \%$ SDS-PAGE gel, followed by transfer to PVDF membranes. The membrane was blocked with 3\% BSA (cat. no. A600332-0100; Sangon Biotech Co., Ltd.) for $1 \mathrm{~h}$ at room temperature, and washed with TBS and 0.1\% Tween-20 (TBST). Subsequently, the membrane was incubated with the relevant primary antibodies at room temperature for $2 \mathrm{~h}$, washed three times with TBST, and then incubated with horseradish peroxidase (HRP)-conjugated anti-rabbit IgG (cat. no. 7074; 1:2,000; Cell Signaling Technology, Inc.) and HRP-conjugated goat anti-mouse IgG (cat. no. ab6789; 1:5,000; Abcam) secondary antibodies for $1 \mathrm{~h}$ at room temperature. After washing in TBST three times, signals were visualized using an enhanced chemiluminescence assay (Biosharp Life Sciences).

Mitochondrial membrane potential analysis. The loss of mitochondrial membrane potential in LPB-treated H460 and H1975 cells was analyzed using a Mitochondrial Membrane Potential Detection JC-1 kit (cat. no. 551302; BD Pharmingen;

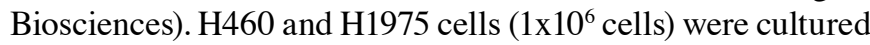


in 6-well plates for $24 \mathrm{~h}$ followed by LPB treatment with the indicated concentrations $(0,20,40$ and $60 \mu \mathrm{M})$ for $24 \mathrm{~h}$ at $37^{\circ} \mathrm{C}$. The cells were harvested and washed with $1 \mathrm{x}$ assay buffer and stained with $\mathrm{JC}-1$ detection reagent for $15 \mathrm{~min}$ at $37^{\circ} \mathrm{C}$. The stained cells were then analyzed using a flow cytometer (BD FACSCanto $^{\mathrm{TM}}$ II Flow cytometer; BD Biosciences) and FlowJo v10.4 software (FlowJo LLC), and the fluorescence intensity in the FITC and PE channels were assessed.

Mitochondrial isolation. The mitochondrial fraction was isolated from cell lysates using a Mitochondria Isolation kit (cat. no. 89874; Thermo Fisher Scientific, Inc.) according to the manufacturer's protocol. Briefly, $800 \mu \mathrm{l}$ Reagent A was added to $2 \times 10^{7} \mathrm{H} 460$ and $\mathrm{H} 1975$ cells, vortexed at 1,500 x g for $5 \mathrm{sec}$, followed by incubation on ice for $2 \mathrm{~min}$. Subsequently, $10 \mu \mathrm{l}$ Reagent B was added to the tubes and vortexed at 3,000 x g for $5 \mathrm{sec}$. Next, $800 \mu \mathrm{l}$ Reagent $\mathrm{C}$ was added to each tube and inverted several times, followed by centrifugation at $700 \mathrm{x} \mathrm{g}$ for $10 \mathrm{~min}$ at $4^{\circ} \mathrm{C}$. The supernatant was transferred to a $2 \mathrm{ml}$ tube and centrifuged at $12,000 \mathrm{x} \mathrm{g}$ for $15 \mathrm{~min}$ at $4^{\circ} \mathrm{C}$. The supernatant was then collected as cytoplasmic protein and the precipitate was centrifuged at $12,000 \mathrm{x}$ g for $5 \mathrm{~min}$ at $4^{\circ} \mathrm{C}$ following addition of $500 \mu \mathrm{l}$ reagent $\mathrm{C}$. Finally, the mitochondrial pellets were lysed using RIPA lysis buffer on ice for $30 \mathrm{~min}$. Western blot analysis was used to detect the expression of proteins in the mitochondrial fraction.

Detection of membrane-bound PD-L1. PD-L1 expressed at the membrane of H460 and H1975 cells was evaluated by flow cytometry. Briefly, single-cell suspensions were collected, and $2.5 \mu \mathrm{Fc}$ block was added and incubated for $10 \mathrm{~min}$ at room temperature. Subsequently, $20 \mu 1 \mathrm{PE}$-conjugated anti-CD274 or anti-IgG (isotype control) was added and incubated for $30 \mathrm{~min}$ at room temperature. There was no washing step between the two staining steps. After staining, cells were washed twice in PBS and then used for flow cytometry analysis with FlowJo v10.4 software (FlowJo LLC).

Reverse transcription-quantitative PCR (RT-qPCR). Total RNA was extracted from cells using TRIzol reagent (cat. no. 15596-026; Ambion; Thermo Fisher Scientific, Inc.). RT was performed using HiScript II Select RT SuperMix for qPCR (cat. no. R232-01; Vazyme Biotech Co., Ltd.) and qPCR analysis was performed using SYBR qPCR Master mix (cat. no. Q311-02; Vazyme Biotech Co., Ltd.). The RT reaction conditions were as follows: $50^{\circ} \mathrm{C}$ for $15 \mathrm{~min}$ and $85^{\circ} \mathrm{C}$ for $5 \mathrm{sec}$, followed by preservation at $4^{\circ} \mathrm{C}$. The qPCR thermocycling conditions were as follows: Pretreatment at $95^{\circ} \mathrm{C}$ for $30 \mathrm{sec}$; followed by 40 cycles at $95^{\circ} \mathrm{C}$ for $10 \mathrm{sec}, 60^{\circ} \mathrm{C}$ for $30 \mathrm{sec}$ and then preservation at $4^{\circ} \mathrm{C}$. The sequences of the primers used were: PD-L1 forward, 5'-CCTACTGGCATTTGCTGAACG CAT-3' and reverse, 5'-ACCATAGCTGATCATGCA GCGGTA-3'; $\beta$-actin forward, 5'-ATCTGGCACCACACCT-3' and reverse, 5'-CGTCATACTCCTGCTT-3'. The $2^{-\Delta \Delta \mathrm{Cq}}$ method (19) was used to analyze the expression of mRNA. Relative abundance was expressed as the ratio of the analyzed gene to $\beta$-actin.

Cell cycle staining. Following treatment with LPB (0, 20, 40 and $60 \mu \mathrm{M}$ ) for $24 \mathrm{~h}$ at $37^{\circ} \mathrm{C}$, cells were collected by centrifugation at $500 \mathrm{x} \mathrm{g}$ for $5 \mathrm{~min}$ at room temperature. The cells were resuspended in $1 \mathrm{ml}$ PBS and $3 \mathrm{ml}$ absolute ethanol was added; the tube was gently vortexed whilst adding ethanol, and subsequently, the cells were left to fix at $-20^{\circ} \mathrm{C}$ overnight. The fixed cells were centrifuged at $500 \mathrm{x}$ g for $10 \mathrm{~min}$ at room temperature, the ethanol was discarded, and 1-2 ml PBS was added and left at room temperature for $10 \mathrm{~min}$. Following centrifugation at $500 \mathrm{x} \mathrm{g}$ for $5 \mathrm{~min}$ at room temperature, $1 \mathrm{ml}$ DNA staining solution (cat. no. CCS012; MultiSciences Biotech Co., Ltd.) was added to the tube, and incubated for $30 \mathrm{~min}$ at room temperature in the dark. A flow cytometer was used to detect cell cycle distribution and FlowJo v10.4 software (FlowJo LLC) was used for analysis.

Lentiviral transfection. A total of $5 \times 10^{5}$ cells were seeded into a 6-well plate before transfection. Following incubation overnight, $50 \mu$ l GFP-RFP-LC3 (Hanbio Biotechnology Co., Ltd.) was added to the plate along with $5 \mu \mathrm{g} / \mathrm{ml}$ polybrene (Hanbio Biotechnology Co., Ltd.). Subsequently, cells were centrifuged at $1,000 \mathrm{x}$ g for $1 \mathrm{~h}$ at room temperature. Following transfection for $48 \mathrm{~h}$, successfully transfected cells were used to detect and analyze autophagy. Images were captured with a fluorescence microscope (magnification, x200).

Statistical analysis. All experiments were repeated independently at least three times. Data are expressed as the mean \pm standard deviation. Significant differences between the control and treatment groups were assessed using one-way ANOVA followed by Dunnett's post hoc test. $\mathrm{P}<0.05$ was considered to indicate a statistically significant difference.

\section{Results}

Liriopesides B suppresses the viability and growth of human NSCLC cells in a dose-dependent manner. The chemical structure of LPB obtained from National Center for Biotechnology Information (www.ncbi.nlm.nih.gov/pccompound/) is presented in Fig. 1A. To investigate whether LPB reduces cell viability of human NSCLC cells, a CCK-8 assay was used to detect the viability of H460 and H1975 cells treated with LPB for 24 and $48 \mathrm{~h}$ (Fig. 1B). The IC50 values of LPB treatment for $24 \mathrm{~h}$ in $\mathrm{H} 460$ and H1975 cells were 42.62 and $32.25 \mu \mathrm{M}$, respectively. Compared with untreated cells, $60 \mu \mathrm{M}$ LPB significantly reduced cell viability of H460 and H1975 cells after $24 \mathrm{~h}$ treatment. Thus, whether treatment with LPB affected clonal growth of human lung cancer cells was assessed. A colony formation assay was performed, and the results demonstrated that LPB suppressed the clonogenic growth of H460 and H1975 cells in a dose-dependent manner (Fig. 1C and D). Additionally, the morphological changes and numbers of H460 and H1975 cells treated with the indicated concentrations were observed using a fluorescence microscope under bright-field (Fig. 1E). These results suggest that LPB inhibits the growth of H460 and H1975 cells.

Liriopesides B induces apoptosis of NSCLC cells. Flow cytometry was used to detect apoptosis of H460 and H1975 cells following treatment with LPB. LPB significantly increased the proportion of apoptotic cells in both H460 and H1975 cells (Fig. 2A). The percentage of apoptotic H460 and 
A

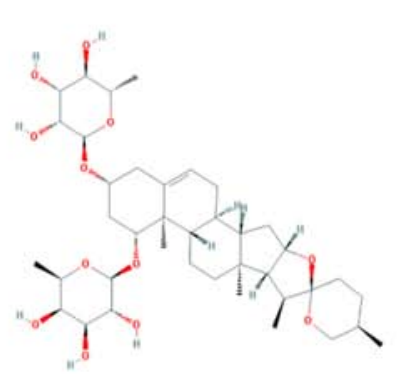

B

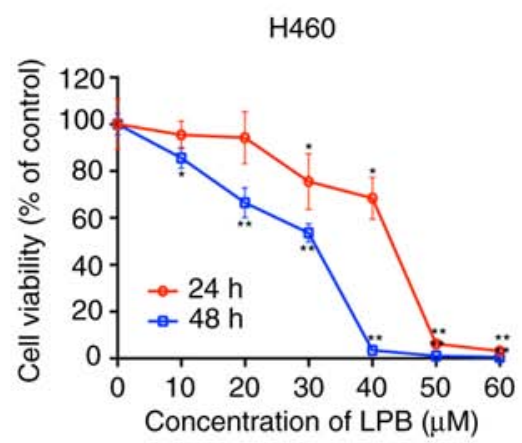

H1975

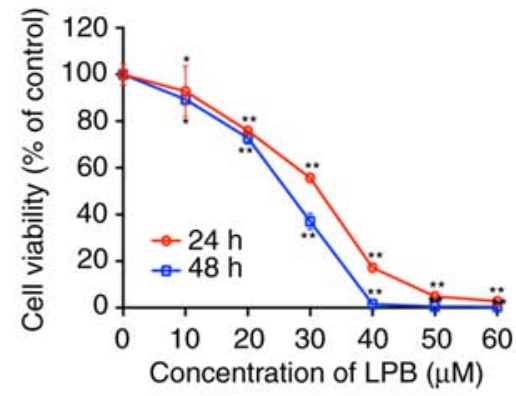

D
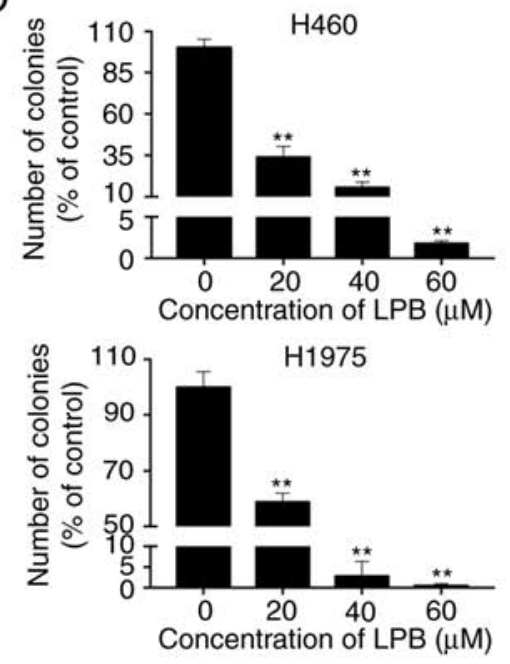

E
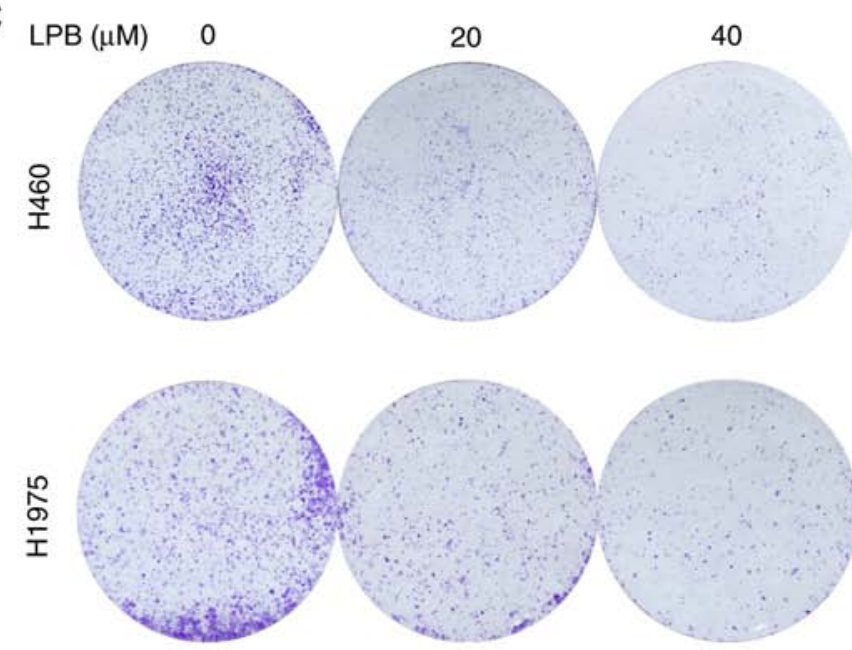

20
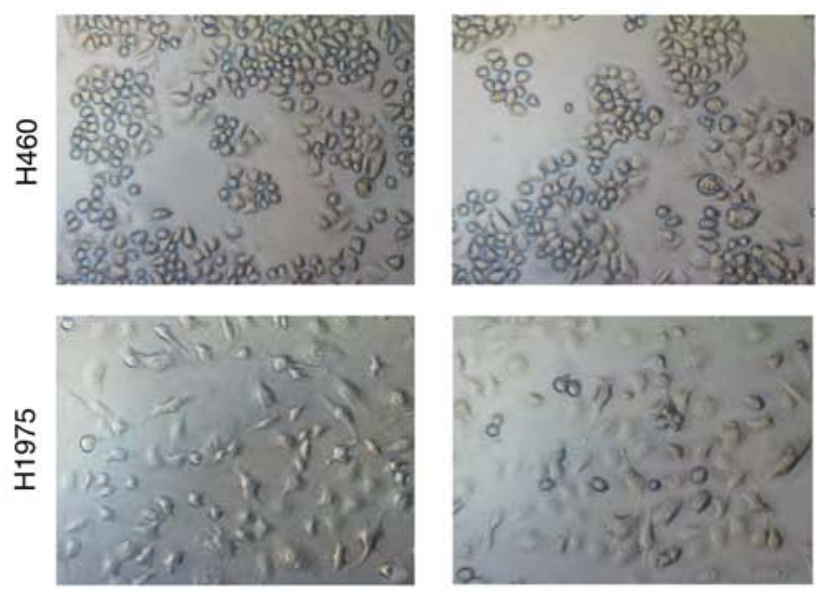

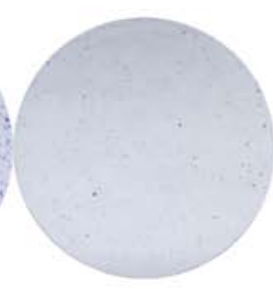

60

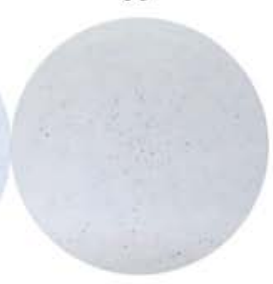

40
60
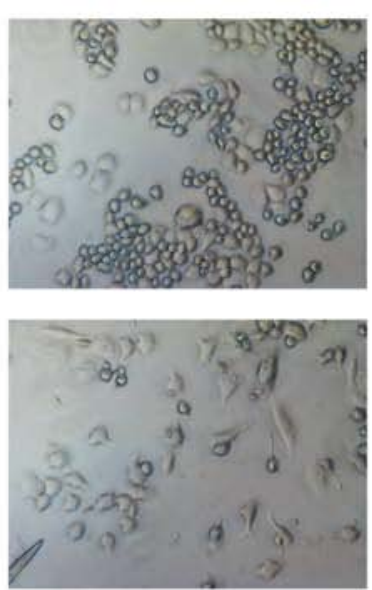
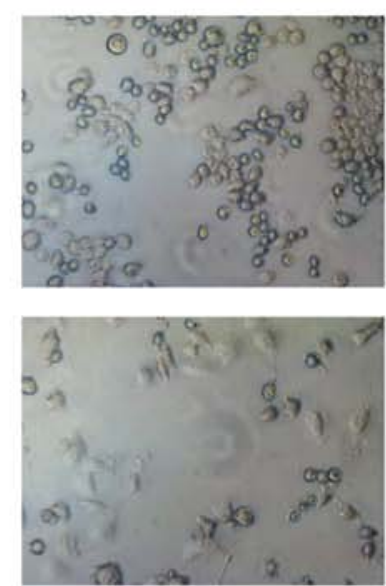

Figure 1. Effect of LPB on the growth of human non-small cell lung cancer cell lines. (A) Chemical structure of LPB obtained from PubChem Compound. (B) A Cell Counting Kit- 8 assay was used to detect the viability of $\mathrm{H} 460$ and $\mathrm{H} 1975$ cells treated with LPB at various concentrations for 24 and 48 h. "P<0.05, ${ }^{* *} \mathrm{P}<0.001$ vs. $0 \mu \mathrm{M}$ LPB. (C) A colony formation assay was used to determine the clonogenic capacity of $\mathrm{H} 460$ and $\mathrm{H} 1975$ cells. Results are representative of at least three independent experiments. (D) Quantitative analysis of the number of colonies formed in cells treated with various concentrations with LPB. ${ }^{* *} \mathrm{P}<0.001$ vs. $0 \mu \mathrm{M}$ LPB. (E) Morphological changes were observed after the cells were treated with LPB at different concentrations for $24 \mathrm{~h}$ using a fluorescence microscope under bright-field. Magnification, x200. Data are presented as the mean \pm standard deviation. LPB, liriopesides B.

H1975 cells after treatment with $60 \mu \mathrm{M}$ LPB was 80.1 and $60.9 \%$, respectively, and in the control, it was 12.7 and $8.3 \%$, respectively. Additionally, the fluorescence images revealed the changes in $\mathrm{H} 460$ and $\mathrm{H} 1975$ cells stained with Hoechst 33342 following treatment with the indicated concentrations of LPB $(0,20,40$ or $60 \mu \mathrm{M})$ for $24 \mathrm{~h}$. Chromatin condensation, DNA fragmentation and cell shrinkage, which are all features of apoptotic cells, was observed under a fluorescence microscope (Fig. 2B). To further investigate the mechanism underlying this phenomenon, expression levels of apoptosis-associated proteins were determined by western blotting (Fig. 2C). The levels of cleaved caspase-3, -8, -9 
A

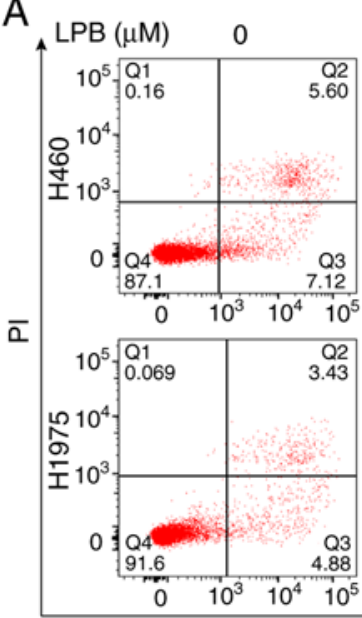

B

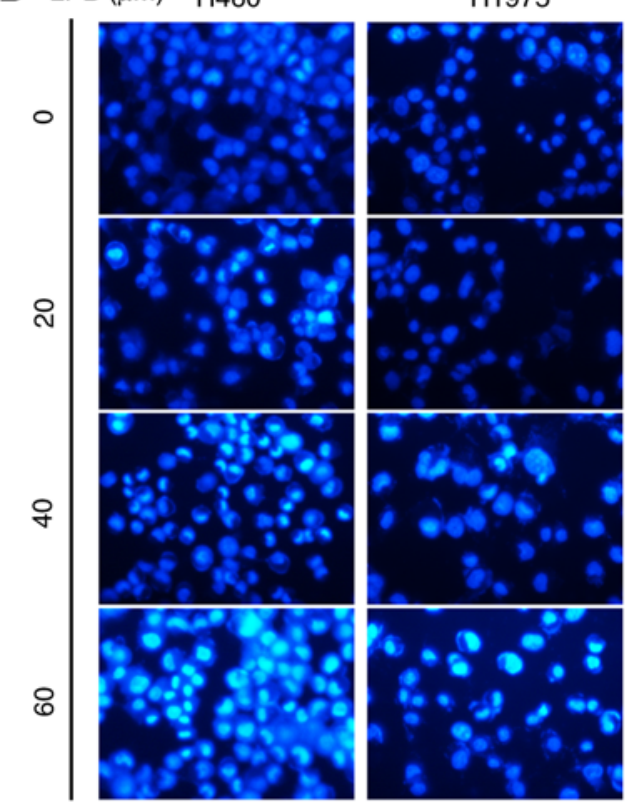

20

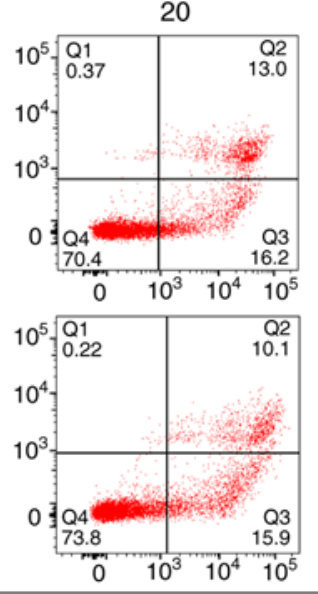

40
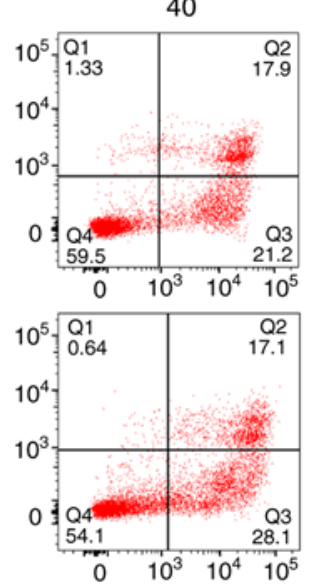
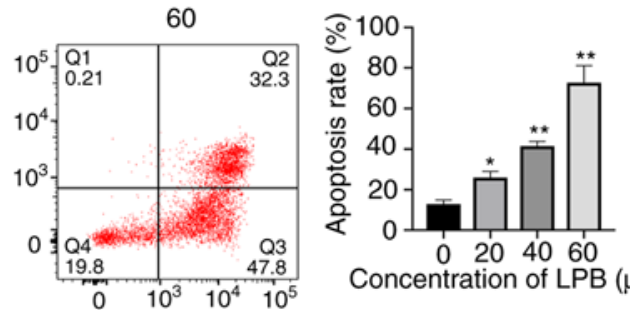

Concentration of LPB $(\mu \mathrm{M})$
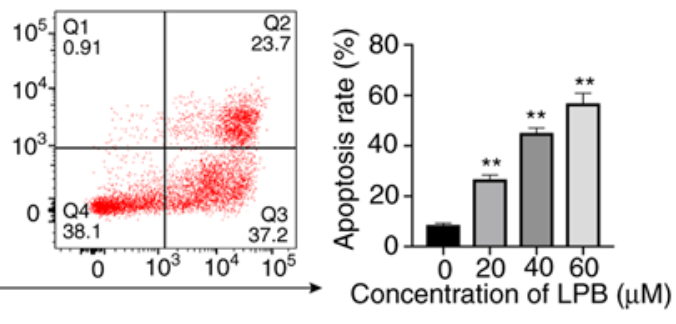

Annexin V-FITC
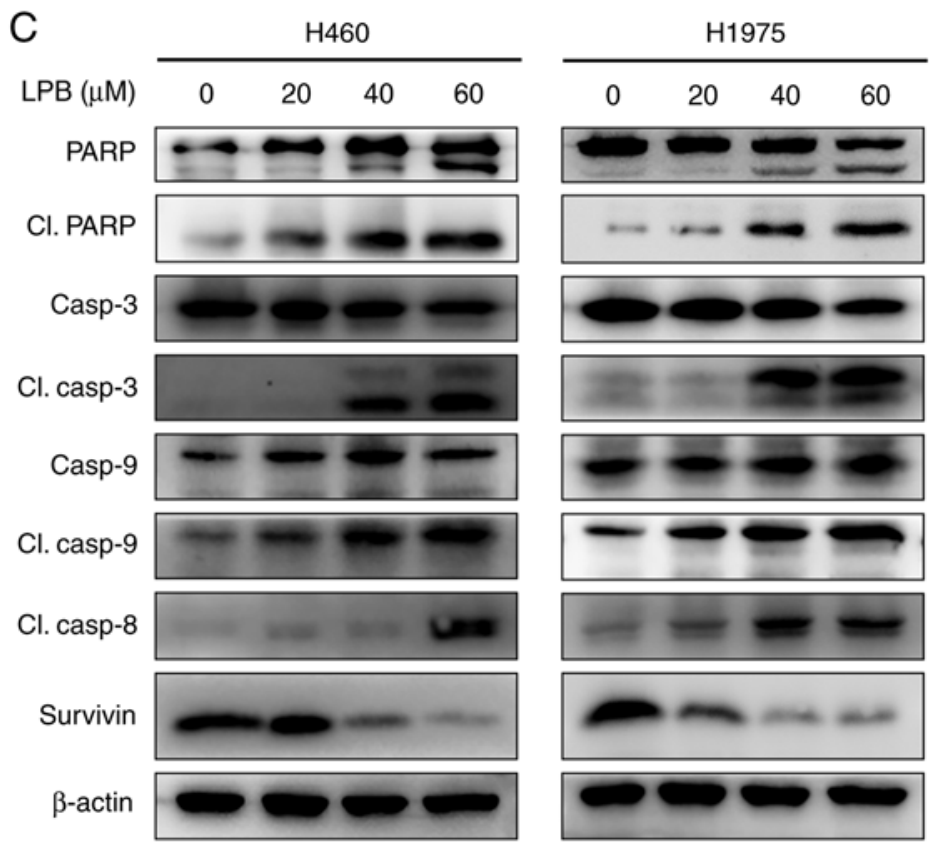

Figure 2. LPB induces apoptosis of H460 and H1975 cells. (A) Annexin V-FITC and PI double staining were used to detect apoptosis induced by different concentrations of LPB for $24 \mathrm{~h} .{ }^{*} \mathrm{P}<0.05,{ }^{* *} \mathrm{P}<0.001$ vs. $0 \mu \mathrm{M}$ LPB. (B) Morphological changes in apoptotic cells treated with LPB are shown by Hoechst 33342 staining using fluorescence microscopy. Magnification, x200. (C) Expression levels of PARP, cleaved PARP, caspase-3, cleaved caspase-3, caspase-9, cleaved caspase-9, cleaved caspase-8 and Survivin were examined by western blotting in H460 and H1975 treated with LPB for 24 h at different concentrations. Results are representative of three independent experiments. LPB, liriopesides B; PARP, poly (ADP-ribose) polymerase.

and PARP increased after $24 \mathrm{~h}$ treatment with the indicated concentrations of LPB both in H460 and H1975 cells, whereas the levels of Survivin decreased, suggesting that LPB induced apoptosis by activating caspases.

Liriopesides B initiates the mitochondrial apoptosis pathway in H460 and H1975 cells. To determine whether the mitochondrial apoptosis pathway is involved in apoptosis, a JC-1 staining assay was performed to detect the mitochondrial membrane potential. The JC-1 probe displayed red fluorescence under normal conditions as the $\mathrm{J}$ aggregates translocated to the inner mitochondrial membrane. However, red fluorescence changed as $\mathbf{J}$ monomers formed in apoptotic cells, which appeared green. These changes indicated a decrease in mitochondrial membrane potential. LPB significantly decreased the mitochondrial membrane potential in both $\mathrm{H} 460$ and H1975 cells (Fig. 3A). Due to their function in mediating mitochondrial membrane permeability, western blot analysis was used to examine the levels of the apoptosis-related proteins (Fig. 3B). The results demonstrated that the expression levels of Bax and tBid, known as pro-apoptotic proteins, were increased, whereas the expression levels of the anti-apoptotic proteins, Bcl-2 and Bcl-xl, were decreased after treatment with LPB. Furthermore, western blotting revealed that the expression of cytochrome $\mathrm{c}$ decreased in the mitochondria and increased in the cytoplasm following treatment with LPB, suggesting that cytochrome c was released from the mitochondria into the cytoplasm to initiate apoptosis. Taken together, these results suggest the mitochondrial apoptosis pathway is involved in LPB-induced apoptosis. 

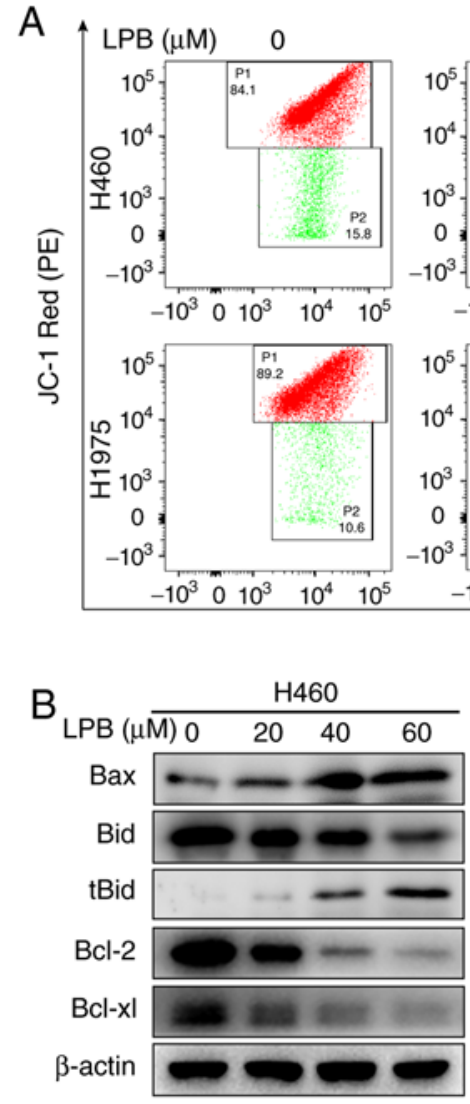

20
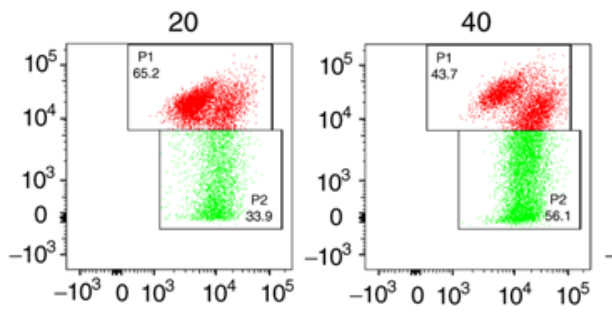

$\begin{array}{lllll}-10^{3} & 0 & 10^{3} & 10^{4} & 10^{5}\end{array}$

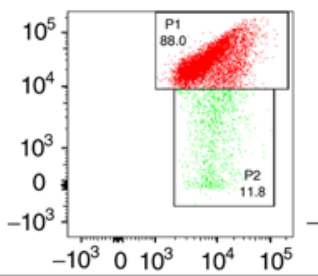

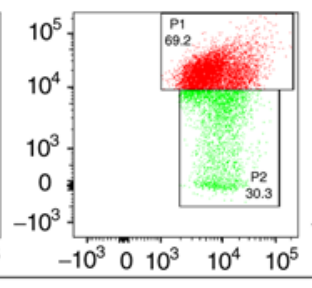

$-10^{3}$
H1975

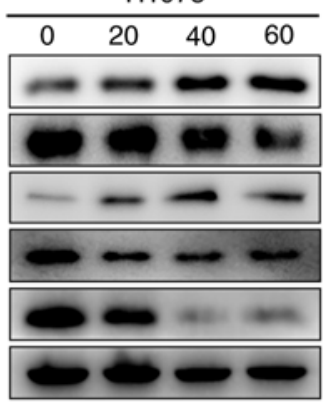

C
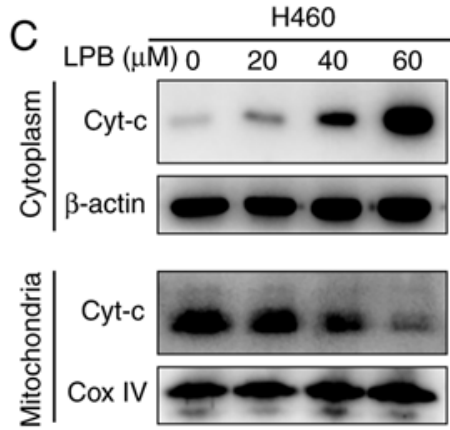

60
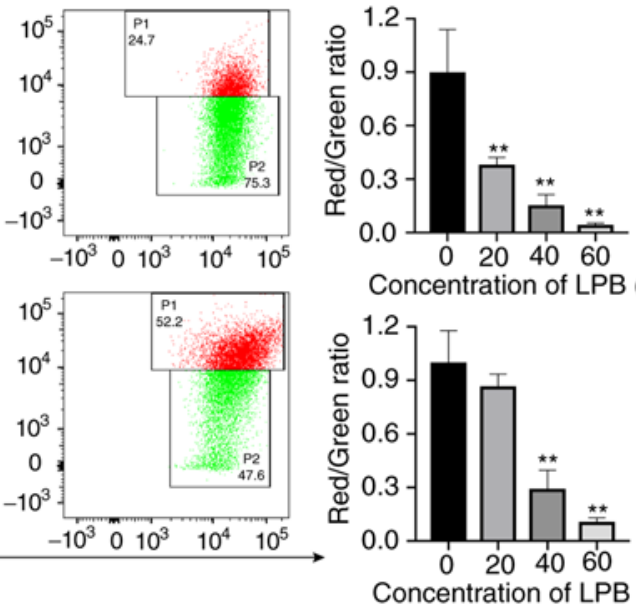

Concentration of LPB $(\mu \mathrm{M})$
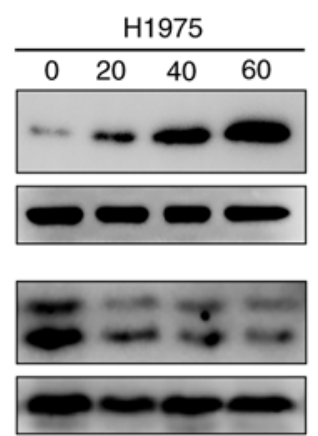

Figure 3. LPB-mediated effects on the mitochondrial apoptosis pathway. (A) Flow cytometry analysis demonstrated that LPB reduced the mitochondrial membrane potential in a dose-dependent manner. ${ }^{* *} \mathrm{P}<0.001$ vs. $0 \mu \mathrm{M} \mathrm{LPB}$. (B) Expression levels of Bax, Bcl-2, Bcl-xl, Bid, tBid, and (C) cytoplasmic and mitochondrial cyt-c were detected by western blotting in $\mathrm{H} 460$ and H1975 cells treated with different concentrations of LPB for 24 h. $\beta$-actin and cox IV were used as the loading controls for the cytoplasm and mitochondria, respectively. Results are representative of three independent experiments. LPB, liriopesides B; cyt-c, cytochrome c.

Liriopesides B induces G1/S arrest in NSCLC cells. Cell cycle arrest is a frequently observed antitumor mechanism of several other traditional Chinese medicines $(20,21)$. As LPB suppressed NSCLC cell growth, its effects on cell cycle progression were assessed. H460 and H1975 cells were treated with LPB for $24 \mathrm{~h}$, and analyzed by flow cytometry. LPB induced G1/S phase arrest in a concentration-dependent manner (Fig. 4A), with the percentage of cells in the G1 phase increasing from 59.5 to $87.4 \%$ in $\mathrm{H} 460$, and increasing from 46.2 to $74.0 \%$ in $\mathrm{H} 1975$ cells in untreated and $60 \mu \mathrm{M}$ group, respectively (Fig. 4B). To determine the underlying mechanism, the expression levels of proteins associated with the G1/S phase checkpoint were assessed, demonstrating that LPB decreased the phosphorylation of $\mathrm{Rb}$, and the total expression of Cyclin D1, Cyclin D3 and CDK6 in both H460 and H1975 cells, whilst upregulating the expression of P21 only in H1975 cells (Fig. 4C). The atypical expression of P21 in H460 cells indicates that there may be some complex regulatory relationship that is not yet clear, therefore further experimental investigations are required. Taken together, these results indicate that LPB induced G1/S phase arrest via a P21-Cyclin D/CDK6 signaling pathway.

LPB activates autophagy via an AMPKo-mTOR signaling pathway in H460 and H1975 cells. Autophagy is a catalytic process that causes autophagic lysosome-mediated degradation of the main contents of the cytoplasm, abnormal protein aggregation and damaged organelles, and this serves an important role in tumor development (22). In the present study, there was a notable aggregation of LC3 puncta observed following LPB treatment, and the degree of aggregation increased in a concentration0dependent manner (Fig. 5A). It has been reported that the AMPK-mTOR signaling pathway may regulate autophagy (23), and thus the effect of LPB on this pathway was assessed in NSCLC cells. Western blotting demonstrated that LPB reduced the levels of p-mTOR, and increased phosphorylation of AMPK $\alpha$ and ULK (Fig. 5B). The expression levels of LC3 were also increased following treatment with LPB for $24 \mathrm{~h}$ in both H460 and H1975 cells (Fig. 5B). Taken together, LPB may induce autophagy in H460 and H1975 cells via an AMPK $\alpha$-mTOR signaling pathway.

Liriopesides $B$ inhibits mitogen-activated protein kinase (MAPK) and AKT signaling pathways in NSCLC cells. The MAPK signaling pathway is involved in several aspects of maintaining cell survival (24). To investigate the mechanism by which LPB suppresses the proliferation of NSCLC cells, the MAPK signaling pathway was assessed by western blotting. Three classical pathways, ERK1/2, p38/MAPK and c-JNK, are involved in the MAPK signaling pathway (25). The activation of protein kinases was evaluated by western blot analysis to determine the effect of LPB on them. LPB 


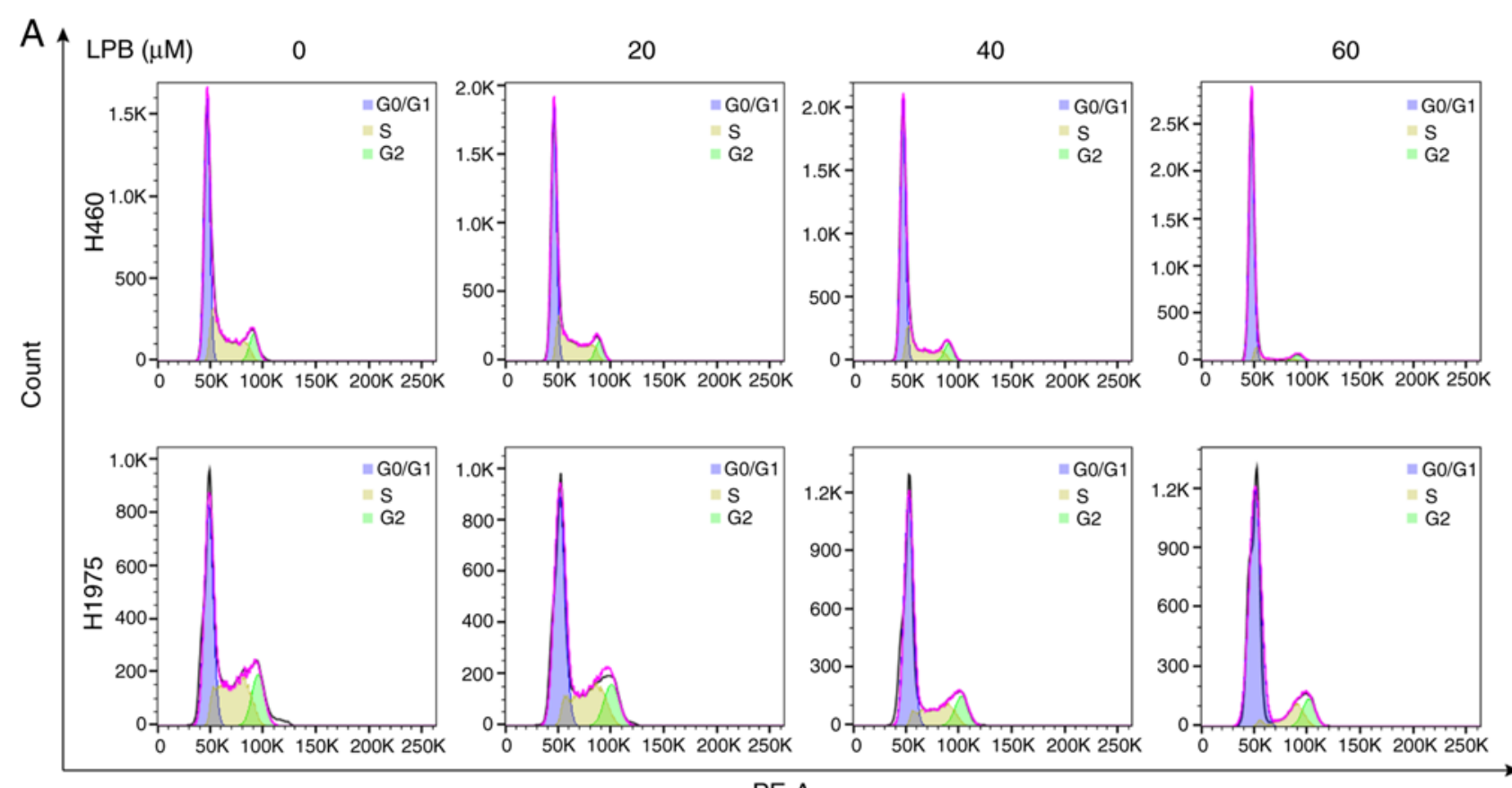

B

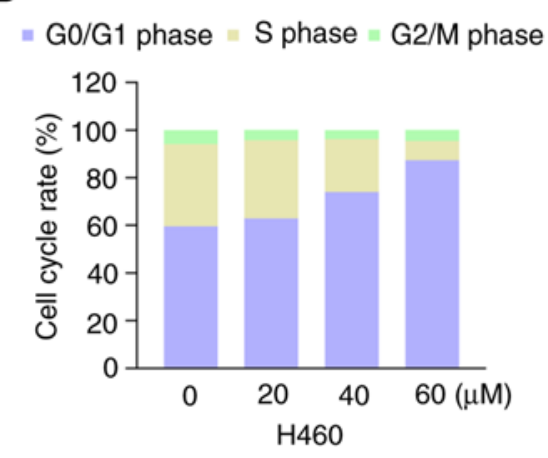

" G0/G1 phase $=\mathrm{S}$ phase $=\mathrm{G} 2 / \mathrm{M}$ phase

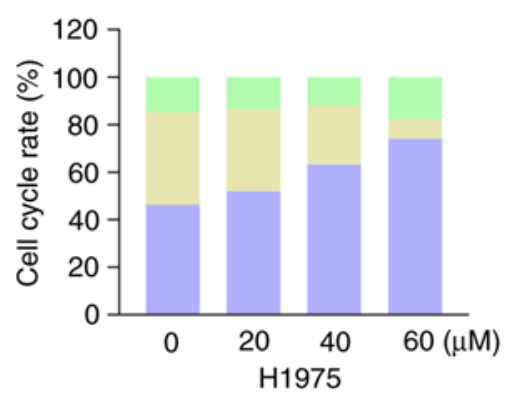

C
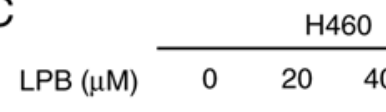

$\mathrm{p}-\mathrm{Rb}$

$\begin{array}{llll}0 & 20 & 40 & 60\end{array}$

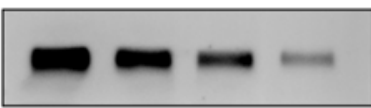

$\mathrm{Rb}$

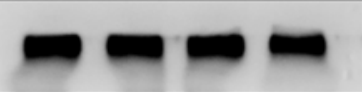

Cyclin D1

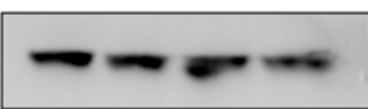

Cyclin D3

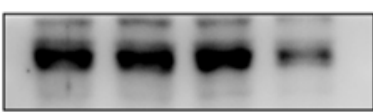

CDK6

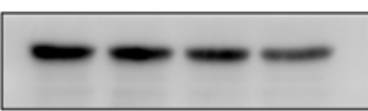

P21

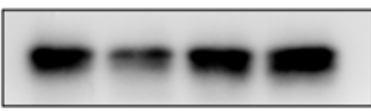

GAPDH

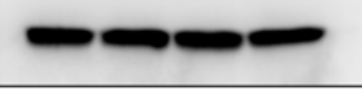

$\mathrm{H} 1975$
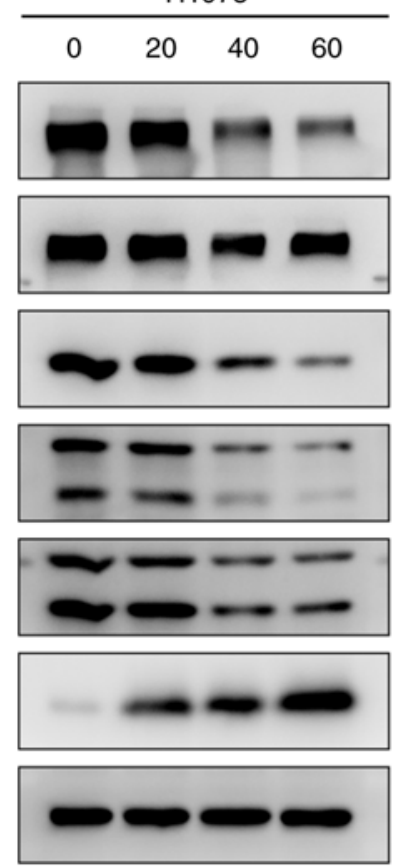

Figure 4. LPB induces cell cycle arrest in non-small cell lung cancer cells. (A) Flow cytometry was used to detect the cell cycle distribution after treatment with LPB. (B) Quantitative analysis of cell cycle distribution. (C) Expression levels of proteins associated with the G1/S checkpoint were measured using western blotting. GAPDH was used as the loading control. Results are representative of three independent experiments. LPB, liriopesides B; Rb, riboblastoma; p-, phosphorylated.

decreased ERK1/2 phosphorylation in a dose-dependent manner in both $\mathrm{H} 460$ and $\mathrm{H} 1975$ cells, and increased p38/MAPK and JNK phosphorylation (Fig. 6). Similar to the MAPK signaling pathway, the level of phosphorylated AKT was reduced by LPB.

Liriopesides B decreases the expression of PD-L1 in H460 and $H 1975$ cells. It has been reported that PD-L1 translocates to the tumor cell membrane and binds to PD-1, which is expressed on the T-cell membrane to exert immune escape (26). Thus, the expression of PD-L1 on the surface of H460 and H1975 cells was assessed by flow cytometry in the present study. The levels of PD-L1 expressed on the cell membrane of H460 and H1975 significantly decreased following treatment with LPB (Fig. 7A). The total PD-L1 expression levels were determined using western blotting (Fig. 7B) and RT-qPCR (Fig. 7C). The 
A
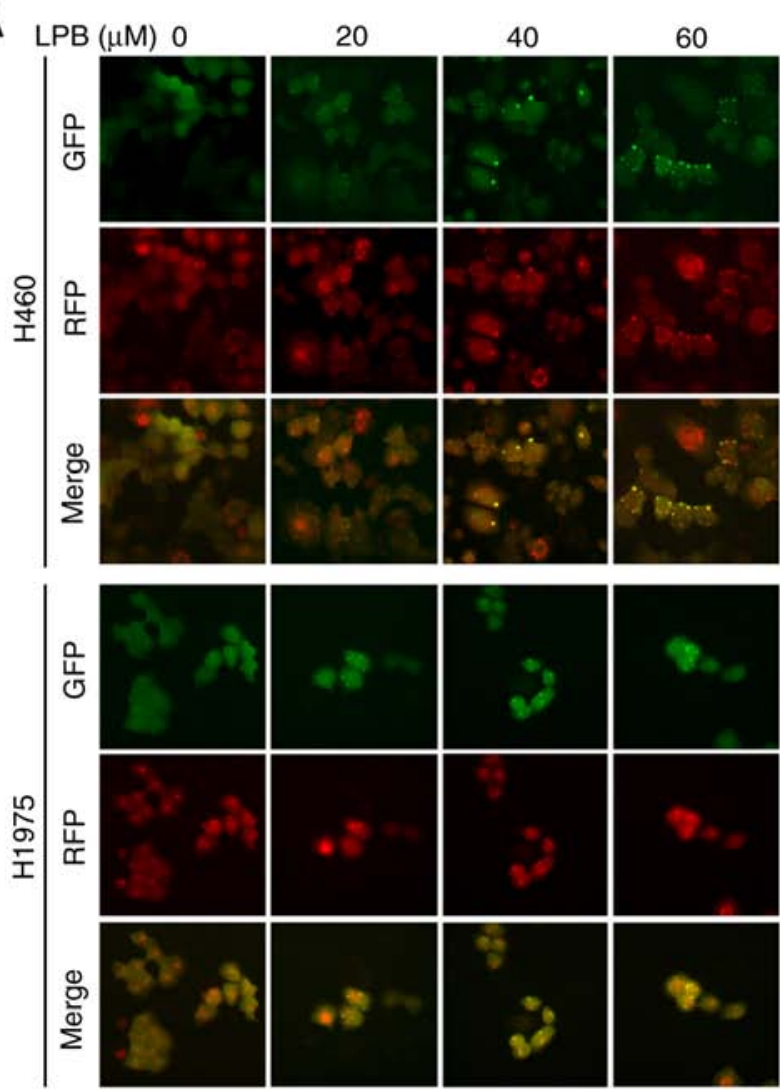

$\mathrm{B}$
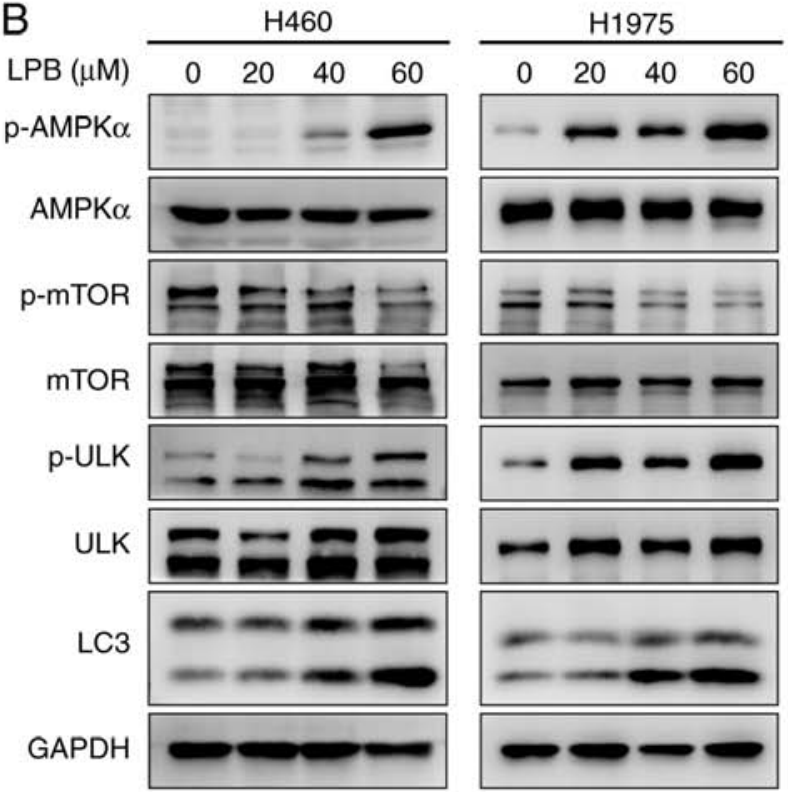

Figure 5. LPB induces autophagy via an AMPK $\alpha$-mTOR signaling pathway in H460 and H1975 cells. (A) H460 and H1975 cells, stably expressing GFP-RFP-LC3, were treated with LPB. Representative images of LC3 puncta captured using a fluorescence microscope are presented. Magnification, x200. (B) AMPK $\alpha$, p-AMPK $\alpha$, p-mTOR, mTOR, p-ULK, ULK, and LC3 expression was detected using western blotting in H460 and H1975 cells treated with LPB. LPB, liriopesides B; p-, phosphorylated; AMPK $\alpha$, AMP-activated protein kinase $\alpha$; ULK, Unc-51 like autophagy activating kinase.

results demonstrated that PD-L1 expression was suppressed by LPB in a dose-dependent manner. These results indicate LPB reduced both the total expression of $\mathrm{PD}-\mathrm{L} 1$ and the expression of PD-L1 at the cell membrane of H460 and H1975 cells.

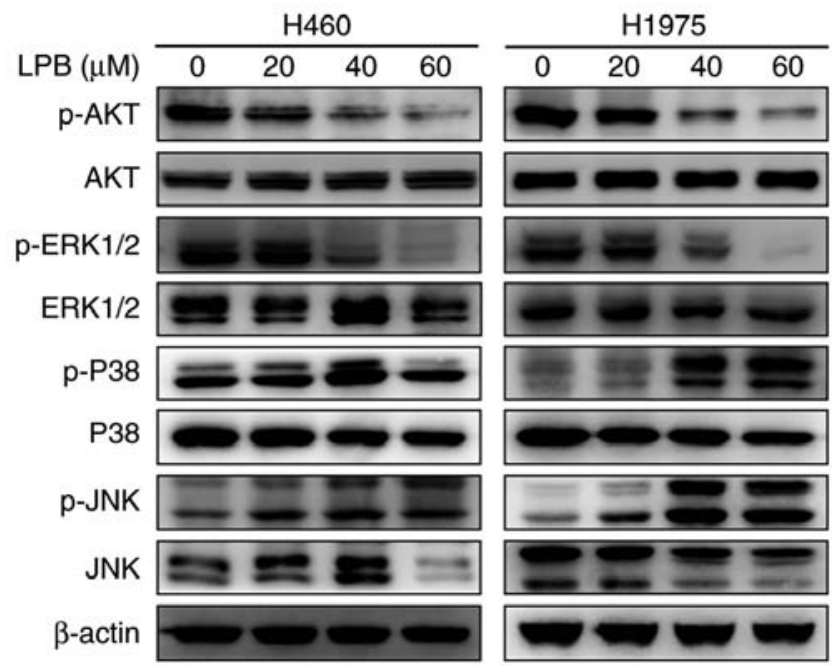

Figure 6. Effect of LPB on the MAPK and AKT signaling pathways in non-small cell lung cancer cells. H460 and H1975 cells were treated with different concentrations of LPB for $24 \mathrm{~h}$. Expression levels of p-AKT, AKT, p-ERK1/2, ERK1/2, p-P38, P38, p-JNK and JNK were detected by western blotting. Results are representative of three independent experiments. LPB Liriopesides B; p-, phosphorylated.

\section{Discussion}

Cancer is the second leading cause of death worldwide, accounting for $\sim 10$ million deaths in 2018 (1). In addition, lung cancer is the most commonly diagnosed cancer and the leading cause of cancer-associated mortality (1). Although cancer diagnoses and treatment techniques have improved significantly, a notable proportion of patients are diagnosed in the first instance with advanced stage cancer (27). In addition, chemotherapy remains the primary treatment for people with advanced stage or relapsed tumors (28). Due to the various adverse reactions and/or the development of multidrug resistance with current chemotherapy regimens, a safe and effective adjuvant therapy or reagent is required. Natural compounds, isolated from medicinal plants, are potential resources for the development of novel chemotherapeutic reagents including steroidal saponins, which exhibit antitumor functions $(29,30)$. Whilst the exact mechanisms underlying the effects of these compounds are not yet fully understood, some reagents have been used to treat cancer patients with fewer side effects than established treatments (31). The anti-bacterial activity, memory enhancement effect and anti-inflammatory effects of spicatoside A (SPA) have been shown in several studies $(11,32,33)$. It has also been reported that SPA may suppress the proliferation of colon cancer cells via cell cycle regulation and apoptosis (34). Therefore, in the present study, the effects of LPB, which contains a similar active compound to SPA, on NSCLC cells were assessed.

The CCK-8 assay, colony formation assay and phase-contrast microscopy demonstrated that LPB significantly reduced cell viability and clonogenic growth of H460 and H1975 cells in a dose-dependent manner. Apoptosis, also referred to as programmed cell death $\mathrm{I}$, is a desirable outcome of traditional cancer therapy, including chemotherapy and radiotherapy (35). The results suggested that LPB increased cleavage of caspase- 8 into its active form, and cleaved caspase- 8 
A

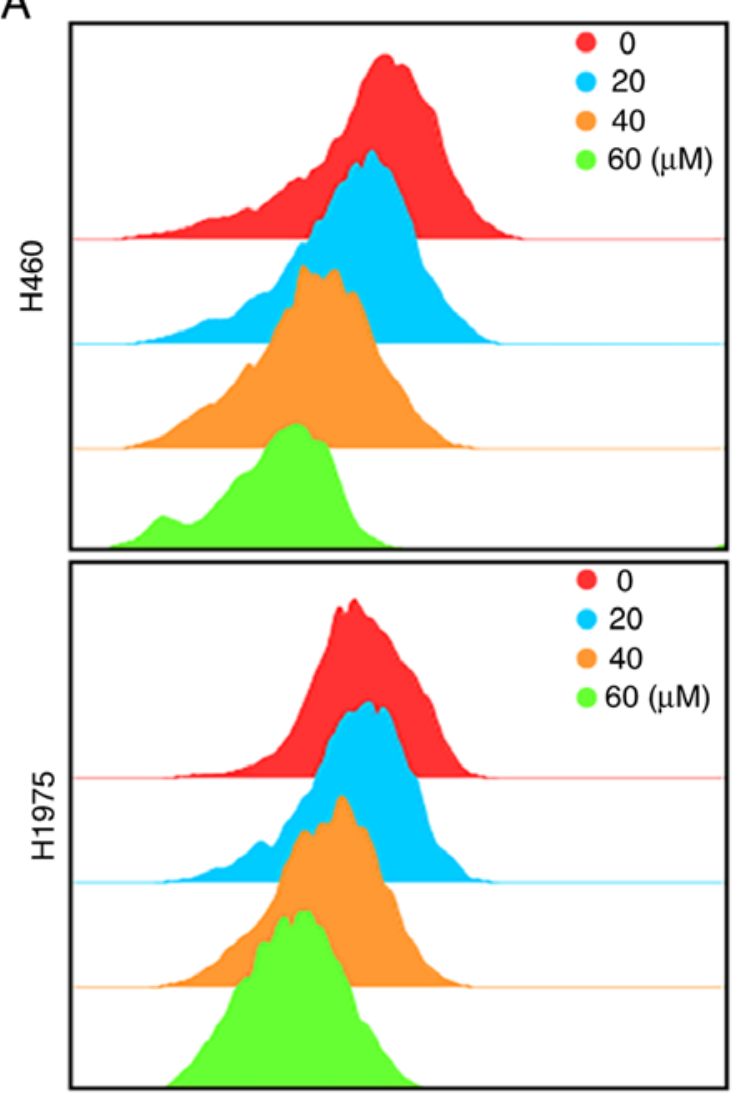

B

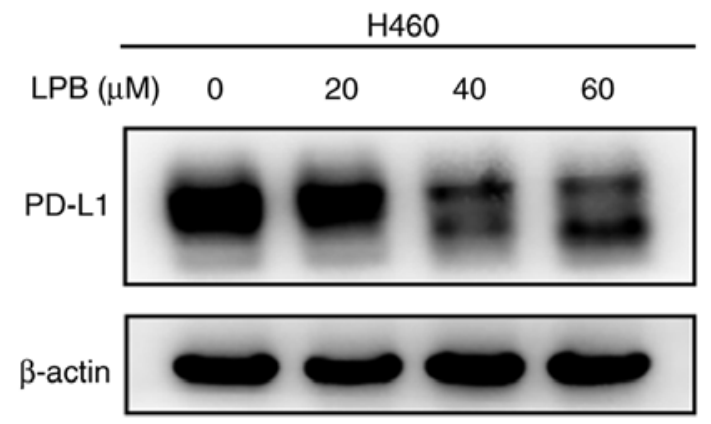

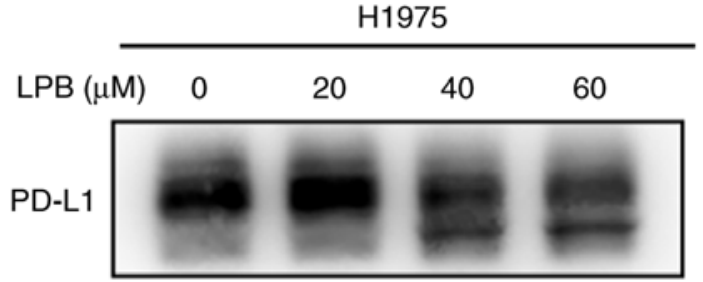

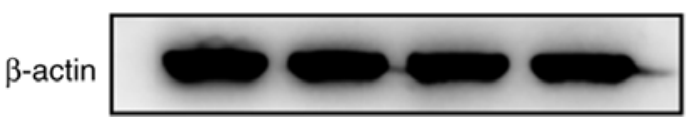

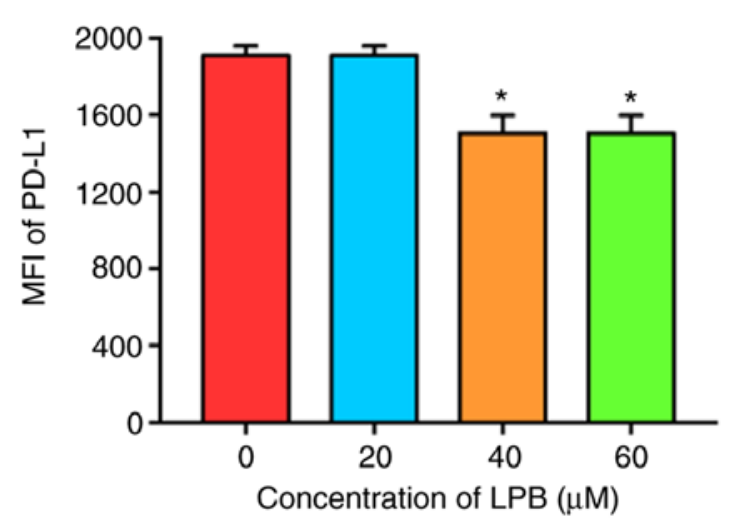
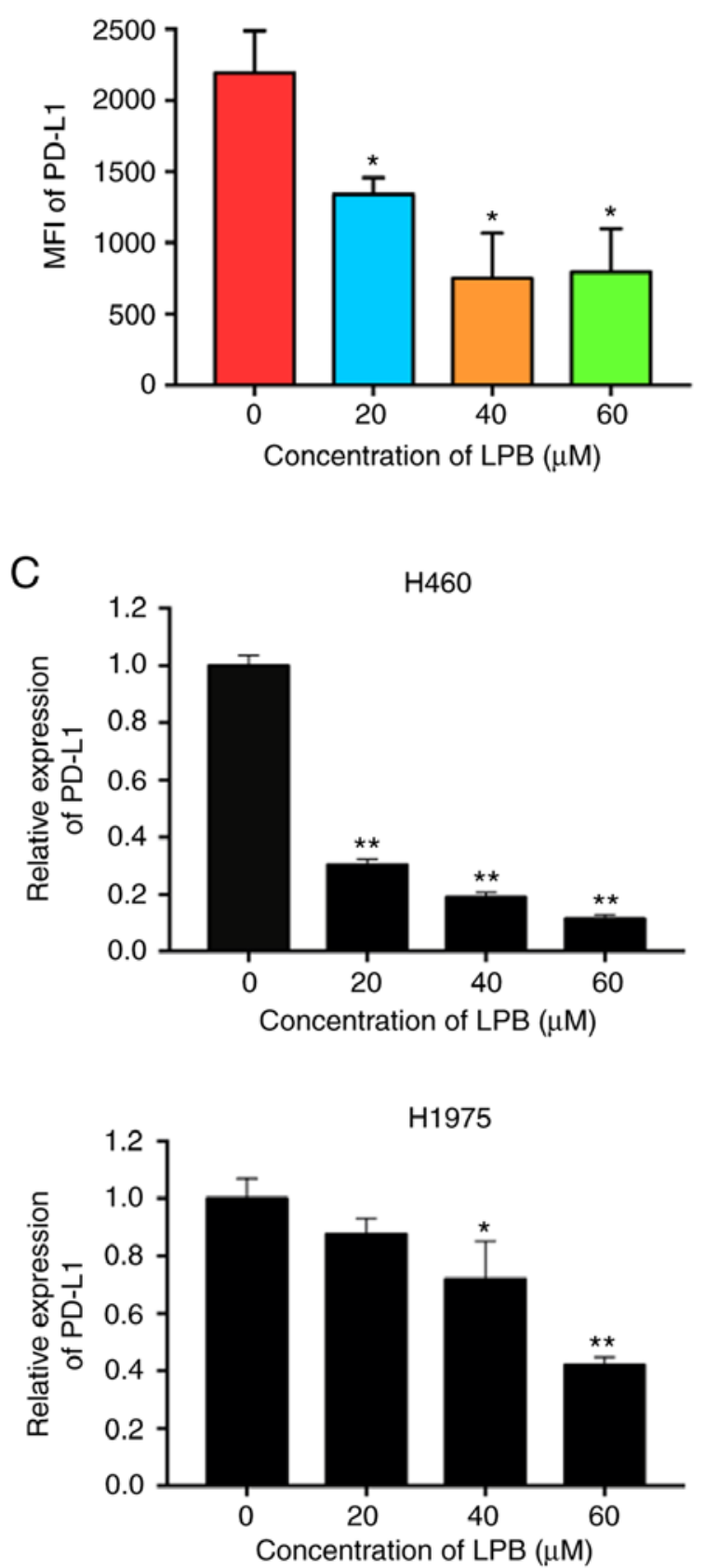

Figure 7. LPB decreases the total expression levels of PD-L1 and at the cell membrane. (A) Flow cytometry analysis was used to examine the expression of PD-L1 on the cell membrane of the non-small cell lung cancer cells. The MFI of PD-L1 was significantly decreased by LPB in both H460 and H1975 cells. ${ }^{*} \mathrm{P}<0.05$. (B) Western blotting and (C) reverse transcription-quantitative PCR were performed to detect the total expression levels of PD-L1. Results are representative of three independent experiments. Data are presented as the mean \pm standard deviation. ${ }^{*} \mathrm{P}<0.05,{ }^{* * *} \mathrm{P}<0.001$ vs. $0 \mu \mathrm{M} \mathrm{LPB}$. MFI, mean fluorescence intensity; LPB, liriopesides B; MFI, mean fluorescence intensity; PD-L1, programmed death-ligand 1. 
shears Bid to tBid, which is then translocated to the mitochondrial outer membrane and interacts with Bax/Bcl-2 (36) to alter the mitochondrial membrane potential (37). These changes eventually contribute to the increase in permeability of the mitochondrial membrane, leading to the release of cytochrome $\mathrm{c}$ from the mitochondria into the cytoplasm. Cytochrome $\mathrm{c}$ is a well-conserved electron-transport protein and is part of the respiratory chain localized in the mitochondrial intermembrane space (38). Cytochrome c, released from the mitochondria, can integrate with pro-caspase-9/apoptotic protease activating factor 1 in the cytoplasm and this complex cleaves caspase- 9 from an inactive proenzyme to its active form, cleaved caspase-9 (39). This event further triggers the activation of caspase-3, and finally, PARP is cleaved by the activated caspases, leading to nuclear condensation and apoptotic cell death (40).

Additionally, LPB induced G1/S phase arrest, as detected by flow cytometry, by decreasing the expression of Cyclin D1, Cyclin D3 and CDK6, whilst increasing the expression of $\mathrm{P} 21$. These results suggest that cell cycle arrest also serves a role in the antitumor effects of LPB. Notably, it was identified that LPB could cause cell cycle arrest in the G1 phase at low concentrations, while apoptotic cells appeared when the concentration was increased to a certain level. The possible explanation of this phenomenon is that following stimulation by LPB, the cell cycle paused to repair DNA damage, but as the compound concentration increases, the outcome for cells that cannot repair the damage goes to death, including apoptosis. Furthermore, LPB may significantly induce autophagy via the AMPK-mTOR signaling pathway in H460 and H1975 cells, as notable LC3 puncta were observed. LPB was thus shown to exhibit significant effects on apoptosis, cell cycle arrest and autophagy. However, it is unknown how these effects interact and affect each other, and further investigation is required.

Furthermore, it has been reported that the MAPK pathway serves a vital role in the development and progression of several types of cancer (41). The ERK1/2 signaling pathway serves a critical role in survival (42), and JNK is associated with proapoptotic activities in several tumor cell lines (43-45). Compared with ERK1/2 or JNK, the p38/MAPK signaling pathway displays a relatively complex function. It has been reported that $\mathrm{p} 38 / \mathrm{MAPK}$ may function as a tumor suppressor by increasing apoptosis (46). However, under certain conditions, the p38/MAPK signaling pathway may also initiate resistance to apoptosis $(47,48)$. In the present study, LPB treatment increased p38/MAPK and JNK phosphorylation and decreased ERK1/2 phosphorylation. Therefore, it was hypothesized that LPB induced apoptosis in H460 and H1975 cells via the MAPK signaling pathway.

PD-L1, also known as CD274, has gained increasing attention. When PD-L1 binds with PD-1, it promotes T-cell tolerance and thus immune escape (49). Furthermore, it has been reported that the overexpression of PD-L1 is associated with a poor prognosis in several types of human cancer (50). In the present study, it was shown that LPB may significantly inhibit the expression of PD-L1, both at the transcriptional and translational levels. This suggests that LPB may potentially reduce the expression of $\mathrm{PD}-\mathrm{L} 1$, and thereby suppress immune escape of tumor cells and exert antitumor effects. However, the
PD-L1 inhibition of LPB and its subsequent effects need to be confirmed in vivo.

In conclusion, the antitumor effects of LPB in NSCLC cells were shown for the first time in the present study, to the best of our knowledge. Five novel findings may account for the antitumor effects of LPB: i) Activation of caspases; ii) decrease in mitochondrial membrane potential; iii) induction of G1/S phase arrest; iv) induction of autophagy; and v) inhibition of PD-L1 expression. The effects of LPB on NSCLC cells may be a potential therapeutic strategy, which may circumvent the adverse side effects and drug resistance that are frequently associated with current NSCLC chemotherapy. The promising anticancer mechanisms of LPB should be further studied to establish an efficacious and safe therapeutic strategy for the treatment of NSCLC. In terms of the limitation of this research, whether LPB acts on the cell surface or penetrates into the cell needs to be confirmed by radio-labeling or a fluorescent labeling method. Furthermore, we are currently unable to track the specific effective location or target of our compound in selected cells, which has become a limitation of the present study. This part of the work will be further improved in future research. In addition, further in vivo pharmacological and clinical investigations are required. The results of the present study suggest that LPB may be a promising therapeutic for the treatment of NSCLC.

\section{Acknowledgements}

Not applicable.

\section{Funding}

This study was financially supported by the National Key R\&D Program of China (grant no. 2017YFC0113500), Major Science and Technology Projects of Zhejiang Province (grant no. 2014C03032), Zhejiang Lung Cancer Diagnosis and Treatment Technology Research Center (grant no. JBZX-202007), Zhejiang Provincial Key Discipline of Traditional Chinese Medicine (grant no. 2017-XK-A33), Natural Science Foundation of Zhejiang Province (grant no. LY18H160021), Natural Science Foundation of Zhejiang Province (grant no. LQ20H160050), Zhejiang Traditional Chinese Medicine Scientific Research Fund Program (grant nos. 2016ZA125 and 2018ZB073) and Zhejiang Medical General Research Program (grant no. 2015KYB140).

\section{Availability of data and materials}

The datasets used and/or analyzed during the current study are available from the corresponding author on reasonable request.

\section{Authors' contributions}

HS made substantial contributions to the data collection, analysis and interpretation. JHu and WL designed the study. $\mathrm{LZ}$ and JHa were mainly responsible for experiments related to flow cytometry and prepared the figures. $\mathrm{LW}$ and $\mathrm{ZW}$ were responsible for experimental data collection and drafting the article. All authors read and approved the final version of the manuscript. 


\section{Ethics approval and consent to participate}

Not applicable.

\section{Patient consent for publication}

Not applicable.

\section{Competing interests}

The authors declare that they have no competing interests.

\section{References}

1. Bray F, Ferlay J, Soerjomataram I, Siegel RL, Torre LA and Jemal A: Global cancer statistics 2018: GLOBOCAN estimates of incidence and mortality worldwide for 36 cancers in 185 countries. CA Cancer J Clin 68: 394-424, 2018.

2. Govindan R, Page N, Morgensztern D, Read W, Tierney R, Vlahiotis A, Spitznagel EL and Piccirillo J: Changing epidemiology of small-cell lung cancer in the United States over the last 30 years: Analysis of the surveillance, epidemiologic, and end results database. J Clin Oncol 24: 4539-4544, 2006.

3. Oser MG, Niederst MJ, Sequist LV and Engelman JA: Transformation from non-small-cell lung cancer to small-cell lung cancer: Molecular drivers and cells of origin. Lancet Oncol 16: e165-e172, 2015.

4. Nawa T: Low-dose CT screening for lung cancer reduced lung cancer mortality in Hitachi City. Int J Radiat Biol 95: 1441-1446, 2019.

5. Hoffman PC, Mauer AM and Vokes EE: Lung cancer. Lancet 355: 479-485, 2000

6. Siegel RL, Miller KD and Jemal A: Cancer statistics, 2019. CA Cancer J Clin 69: 7-34, 2019.

7. Ashraf-Uz-Zaman M, Bhalerao A, Mikelis CM, Cucullo L and German NA: Assessing the current state of lung cancer chemoprevention: A comprehensive overview. Cancers (Basel) 12: E1265, 2020.

8. Hur J, Lee P, Moon E, Kang I, Kim SH, Oh MS and Kim SY: Neurite outgrowth induced by spicatoside A, a steroidal saponin, via the tyrosine kinase A receptor pathway. Eur J Pharmacol 620: 9-15, 2009.

9. Lee YC, Lee JC, Seo YB and Kook YB: Liriopis tuber inhibit OVA-induced airway inflammation and bronchial hyperresponsiveness in murine model of asthma. J Ethnopharmacol 101: $144-152,2005$.

10. Kim SW, Chang IM and Oh KB: Inhibition of the bacterial surface protein anchoring transpeptidase sortase by medicinal plants. Biosci Biotechnol Biochem 66: 2751-2754, 2014.

11. Kwon G, Lee HE, Lee DH, Woo H, Park SJ, Gao Q, Ahn YJ, Son KH and Ryu JH: Spicatoside A enhances memory consolidation through the brain-derived neurotrophic factor in mice. Neurosci Lett 572: 58-62, 2014.

12. Chan JY,Koon JC,Liu X, Detmar M, Yu B, Kong SK and Fung KP. Polyphyllin D, a steroidal saponin from Paris polyphylla, inhibits endothelial cell functions in vitro and angiogenesis in zebrafish embryos in vivo. J Ethnopharmacol 137: 64-69, 2011.

13. Sy LK, Yan SC, Lok CN, Man RYK and Che CM: Timosaponin A-III induces autophagy preceding mitochondria-mediated apoptosis in HeLa cancer cells. Cancer Res 68: 10229-10237, 2008.

14. Wang Y, Tang Q, Jiang S, Li M and Wang X: Anti-colorectal cancer activity of macrostemonoside $\mathrm{A}$ mediated by reactive oxygen species. Biochem Biophys Res Commun 441: 825-830, 2013 .

15. Wang Y, Che CM, Chiu JF and He QY: Dioscin (saponin)-induced generation of reactive oxygen species through mitochondria dysfunction: A proteomic-based study. J Proteome Res 6: 4703-4710, 2007.

16. Neychev VK, Nikolova E, Zhelev N and Mitev VI: Saponins from Tribulus terrestris L are less toxic for normal human fibroblasts than for many cancer lines: Influence on apoptosis and proliferation. Exp Biol Med (Maywood) 232: 126-133, 2007.

17. Naveed MA, Riaz N, Saleem M, Jabeen B, Ashraf M, Ismail T and Jabbar A: Longipetalosides A-C, new steroidal saponins from Tribulus longipetalus. Steroids 83: 45-51, 2014.
18. Wang $\mathrm{H}, \mathrm{Yu} \mathrm{H}$, Sun $\mathrm{Y}$, Zhao H, Guo Z and Yu B: Liriopesides B inhibited cell growth and decreased CA125 level in human ovarian cancer A2780 cells. Nat Prod Res 31: 2198-2202, 2017.

19. Livak KJ and Schmittgen TD: Analysis of relative gene expression data using real-time quantitative PCR and the 2(-Delta Delta $\mathrm{C}(\mathrm{T})$ ) method. Methods 25: 402-408, 2001.

20. Fan L, Li L, Yu X, Liang Z, Cai T, Chen Y, Xu Y, Hu T, Wu L and Lin L: Jianpiyifei II granules suppress apoptosis of bronchial epithelial cells in chronic obstructive pulmonary disease via inhibition of the reactive oxygen species-endoplasmic reticulum stress-Ca(2+) signaling pathway. Front Pharmacol 11: $581,2020$.

21. Zhang D, Zhang Q, Zheng Y and Lu J: Anti-breast cancer and toxicity studies of total secondary saponin from Anemone raddeana Rhizome on MCF-7 cells via ROS generation and PI3K/AKT/mTOR inactivation. J Ethnopharmacol: 112984, 2020.

22. Mercer CA, Kalippan A and Dennis PB: A novel, human Atg13 binding protein, Atg101, interacts with ULK1 and is essential for macroautophagy. Autophaghy 5: 649-662, 2009.

23. Gu X, Li Y, Chen K, Wang X, Wang Z, Lian H, Lin Y, Rong X, Chu M, Lin J and Guo X: Exosomes derived from umbilical cord mesenchymal stem cells alleviate viral myocarditis through activating AMPK/mTOR-mediated autophagy flux pathway. J Cell Mol Med: May 18, 2020 (Epub ahead of print).

24. Ohguchi H, Harada T, Sagawa M, Kikuchi S, Tai YT, Richardson PG, Hideshima T and Anderson KC: KDM6B modulates MAPK pathway mediating multiple myeloma cell growth and survival. Leukemia 31: 2661-2669, 2017.

25. Fang JY and Richardson BC: The MAPK signalling pathways and colorectal cancer. Lancet Oncol 6: 322-327, 2005.

26. Dong W, Wu X, Ma S, Wang Y, Nalin AP, Zhu Z, Zhang J, Benson DM, He K, Caligiuri MA and Yu J: The mechanism of anti-PD-L1 antibody efficacy against PD-L1-negative tumors identifies NK cells expressing PD-L1 as a cytolytic effector. Cancer Discov 9: 1422-1437, 2019.

27. de Koning HJ, van der Aalst CM, de Jong PA, Scholten ET, Nackaerts K, Heuvelmans MA, Lammers JJ, Weenink C, Yousaf-Khan U, Horeweg N, et al: Reduced lung-cancer mortality with volume CT screening in a randomized trial. N Engl J Med 382: 503-513, 2020.

28. Arbour KC and Riely GJ: Systemic therapy for locally advanced and metastatic non-small cell lung cancer: A review. JAMA 322: 764-774, 2019.

29. Awang K, Azmi MN, Aun LI, Aziz AN, Ibrahim H and Nagoor NH: The apoptotic effect of 1's-1'-acetoxychavicol acetate from Alpinia conchigera on human cancer cells. Molecules 15: 8048-8059, 2010

30. Yeh CC, Tseng CN, Yang JI, Huang HW, Fang Y, Tang JY, Chang FR and Chang HW: Antiproliferation and induction of apoptosis in Ca9-22 oral cancer cells by ethanolic extract of Gracilaria tenuistipitata. Molecules 17: 10916-10927, 2012.

31. Normile D: Asian medicine. The new face of traditional chinese medicine. Science 299: 188-190, 2003.

32. Lim H, Min DS, Kang Y, Kim HW, Son KH and Kim HP: Inhibition of matrix metalloproteinase-13 expression in IL-1 $\beta$-treated articular chondrocytes by a steroidal saponin, spicatoside A, and its cellular mechanisms of action. Arch Pharm Res 38: 1108-1116, 2015.

33. Park SH, Lee HJ, Ryu J, Son KH, Kwon SY, Lee SK, Kim YS, Hong JH, Seok JH and Lee CJ: Effects of ophiopogonin D and spicatoside A derived from Liriope Tuber on secretion and production of mucin from airway epithelial cells. Phytomedicine 21: 172-176, 2014.

34. Kim WK, Pyee Y, Chung HJ, Park HJ, Hong JY, Son KH and Lee SK: Antitumor activity of spicatoside A by modulation of autophagy and apoptosis in human colorectal cancer cells. J Nat Prod 79: 1097-1104, 2016.

35. Pistritto G, Trisciuoglio D, Ceci C, Garufi A and D'Orazi G: Apoptosis as anticancer mechanism: Function and dysfunction of its modulators and targeted therapeutic strategies. Aging (Albany NY) 8: 603-619, 2016.

36. Luo X, Budihardjo I, Zou H, Slaughter C and Wang X: Bid, a $\mathrm{Bcl} 2$ interacting protein, mediates cytochrome $\mathrm{c}$ release from mitochondria in response to activation of cell surface death receptors. Cell 94: 481-490, 1998.

37. $\mathrm{Li} \mathrm{H}, \mathrm{Zhu} \mathrm{H}, \mathrm{Xu} \mathrm{CJ}$ and Yuan J: Cleavage of BID by caspase 8 mediates the mitochondrial damage in the Fas pathway of apoptosis. Cell 94: 491-501, 1998. 
38. Schägger $\mathrm{H}$ : Respiratory chain supercomplexes of mitochondria and bacteria. Biochim Biophys Acta 1555: 154-159, 2002.

39. Li P, Nijhawan D, Budihardjo I, Srinivasula SM, Ahmad M, Alnemri ES and Wang X: Cytochrome $\mathrm{c}$ and dATP-dependent formation of Apaf-1/caspase-9 complex initiates an apoptotic protease cascade. Cell 91: 479-489, 1997.

40. Liu X, Kim CN, Yang J, Jemmerson R and Wang X: Induction of apoptotic program in cell-free extracts: Requirement for dATP and cytochrome c. Cell 86: 147-157, 1996

41. Khavari TA and Rinn J: Ras/Erk MAPK signaling in epidermal homeostasis and neoplasia. Cell Cycle 6: 2928-2931, 2007.

42. Burotto M, Chiou VL, Lee JM and Kohn EC: The MAPK pathway across different malignancies: A new perspective. Cancer 120: 3446-3456, 2014.

43. Li Y, Zhao L, Sun H, Yu J, Li N, Liang J, Wang Y, He M, Bai X, Yu Z, et al: Gene silencing of FANCF potentiates the sensitivity to mitoxantrone through activation of JNK and p38 signal pathways in breast cancer cells. PLoS One 7: e44254, 2012.

44. Mansouri A, Ridgway LD, Korapati AL, Zhang Q, Tian L, Wang Y, Siddik ZH, Mills GB and Claret FX: Sustained activation of JNK/p38 MAPK pathways in response to cisplatin leads to Fas ligand induction and cell death in ovarian carcinoma cells. J Biol Chem 278: 19245-19256, 2003.

45. Sau A, Filomeni G, Pezzola S, D'Aguanno S, Tregno FP, Urbani A, Serra M, Pasello M, Picci P, Federici G and Caccuri AM: Targeting GSTP1-1 induces JNK activation and leads to apoptosis in cisplatin-sensitive and -resistant human osteosarcoma cell lines. Mol Biosyst 8: 994-1006, 2012.
46. Deacon K, Mistry P, Chernoff J, Blank J and Patel R: p38 Mitogen-activated protein kinase mediates cell death and p21-activated kinase mediates cell survival during chemotherapeutic drug-induced mitotic arrest. Mol Biol Cell 14: 2071-2087, 2003.

47. Salim H, Akbar N, Zong D, Vaculova AH, Lewensohn R, Moshfegh A, Viktorsson K and Zhivotovsky B: MiRNA-214 modulates radiotherapy response of non-small cell lung cancer cells through regulation of p38MAPK, apoptosis and senescence. Br J Cancer 107: 1361-1373, 2012.

48. Chen SF, Nieh S, Jao SW, Liu CL, Wu CH, Chang YC, Yang CY and Lin YS: Quercetin suppresses drug-resistant spheres via the p38 MAPK-Hsp27 apoptotic pathway in oral cancer cells. PLoS One 7: e49275, 2012.

49. Keir ME, Butte MJ, Freeman GJ and Sharpe AH: PD-1 and its ligands in tolerance and immunity. Annu Rev Immunol 26: 677-704, 2008

50. Konishi J, Yamazaki K, Azuma M, Kinoshita I, Dosaka-Akita H and Nishimura M: B7-H1 expression on non-small cell lung cancer cells and its relationship with tumor-infiltrating lymphocytes and their PD-1 expression. Clin Cancer Res 10: 5094-6100, 2004.

(i) $(9)$ This work is licensed under a Creative Commons Attribution-NonCommercial-NoDerivatives 4.0 International (CC BY-NC-ND 4.0) License. 